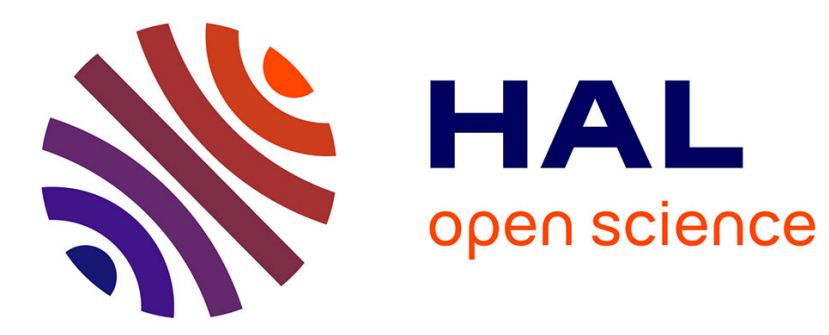

\title{
Unexpected peaks in electron ionisation mass spectra of trimethylsilyl derivatives resulting from the presence of trace amounts of water and oxygen in GC-QTOF systems
}

Jean-Francois Rontani, Claude Aubert

\section{To cite this version:}

Jean-Francois Rontani, Claude Aubert. Unexpected peaks in electron ionisation mass spectra of trimethylsilyl derivatives resulting from the presence of trace amounts of water and oxygen in GC-QTOF systems. Rapid Communications in Mass Spectrometry, 2019, 33 (7), pp.741-743. 10.1002/rcm.8404 . hal-02325891

\section{HAL Id: hal-02325891 \\ https://hal.science/hal-02325891}

Submitted on 21 Apr 2020

HAL is a multi-disciplinary open access archive for the deposit and dissemination of scientific research documents, whether they are published or not. The documents may come from teaching and research institutions in France or abroad, or from public or private research centers.
L'archive ouverte pluridisciplinaire HAL, est destinée au dépôt et à la diffusion de documents scientifiques de niveau recherche, publiés ou non, émanant des établissements d'enseignement et de recherche français ou étrangers, des laboratoires publics ou privés. 
$10.1002 / \mathrm{rcm} .8404$

Rapid communication

Unexpected peaks in mass spectra of trimethylsilyl derivatives resulting from the presence of trace amounts of water and oxygen in GC-QTOF systems

Jean-François Rontani ${ }^{1 *}$

Claude Aubert ${ }^{2}$

${ }^{1}$ Aix Marseille Univ, Université de Toulon, CNRS, IRD, MIO UM 110, 13288 Marseille, France.

${ }^{2}$ Laboratoire de Pharmacocinétique et Toxicocinétique (EA 3286), Faculté de Pharmacie, 13385 Marseille, France.

*Correspondence to:

Jean-François Rontani, Aix Marseille University, Campus de Luminy, Bâtiment 26P, MIO

UM 110, 13288 Marseille, France.

Email: jean-francois.rontani@mio.osupytheas.fr

Silylation is one of the most prevalent derivatization method. Replacement of active hydrogen (in $-\mathrm{OH},-\mathrm{SH}$ or $=\mathrm{NH}$ groups) by a silyl group reduces the polarity of the compound and hydrogen bonding ${ }^{1}$. Electron ionization (EI) mass spectra of trimethylsilyl ethers or esters exhibit a significant $[\mathrm{M}-15]^{+}$ion formed by loss of a methyl group bonded to silicon, which is very useful in determining the molecular mass. EI mass spectra of trimethylsilyl (TMS) derivatives may be employed not only for molecular weight determinations, but also for structural deductions. $^{2}$ They are generally stable during GC-MS analyses, although contamination of the mass spectrometer source with organic substances has been reported to cause some decomposition. ${ }^{3}$ Moreover, it may be noted that if the amount of water is too high 
in the carrier gas (as in the case of saturation of the wet traps) silylated derivatives may be fully or partially desilylated within splitless injectors.

Recently, during analyses carried out in full scan mode with an Agilent 7890B/7200A GC-QTOF system (Agilent Technologies), we observed the presence of unexpected ions in mass spectra of TMS derivatives. The following operating conditions were employed: crosslinked 5\% phenyl-methylpolysiloxane (Agilent; HP-5MS ultra inert) $(30 \mathrm{~m} \times 0.25 \mathrm{~mm}, 0.25$ $\mu \mathrm{m}$ film thickness) capillary column, injector operating in pulsed splitless mode set at $270^{\circ} \mathrm{C}$, oven temperature programmed from $70^{\circ} \mathrm{C}$ to $130^{\circ} \mathrm{C}$ at $20^{\circ} \mathrm{C} \mathrm{min}{ }^{-1}$ and then to $300^{\circ} \mathrm{C}$ at $5^{\circ} \mathrm{C}$ $\min ^{-1}$, pressure of the carrier gas $(\mathrm{He})$ maintained at $0.69 \times 10^{5} \mathrm{~Pa}$ until the end of the temperature program, transfer line and ion source temperatures set at 300 and $230^{\circ} \mathrm{C}$,

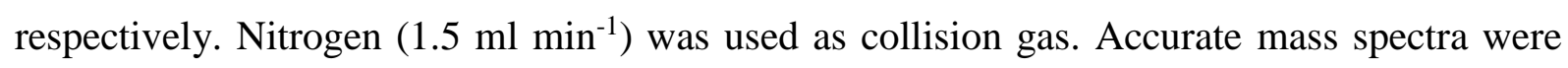
recorded across the range $m / z$ 50-700 at $4 \mathrm{GHz}$ with the collision gas opened. The QTOF-MS instrument provided a typical resolution ranging from 8009 to 12252 from $\mathrm{m} / \mathrm{z} 68.9955$ to 501.9706. Perfluorotributylamine (PFTBA) was utilized for daily MS calibration. After silylation in pyridine-BSTFA $(2: 1, \mathrm{v} / \mathrm{v})$ for $1 \mathrm{~h}$ at $50^{\circ} \mathrm{C}$ and subsequent evaporation to dryness, the samples to be analysed were taken in mixtures of ethyl acetate and BSTFA.

We observed the presence of unexpected fragment ions corresponding to $\left[\mathrm{M}-\mathrm{CH}_{3}+\right.$ $\left.\mathrm{H}_{2} \mathrm{O}\right]^{+}$in mass spectra of TMS derivatives of primary alcohols and fatty acids (Figures. 1A and 1B). These ions resulting likely from the addition of a neutral molecule of water on the $[\mathrm{M}-$ $\left.\mathrm{CH}_{3}\right]^{+}$ions of TMS derivatives in the collision cell (Equation 1), disappeared when a wet trap was added before the collision gas inlet.<smiles>[R]C(=O)[O+]=[Si](C)C</smiles><smiles></smiles>

Unexpected peaks due to reaction of product ions with residual water in mass spectrometer collision cells were previously observed in tandem mass spectra of folic acid, guanosine and related compounds. ${ }^{4,5}$ It seems thus that water addition may also act on product ions resulting from TMS derivative fragmentation. These parasite ions appeared to be particularly prominent in the case of TMS ethers or esters exhibiting intense $\left[\mathrm{M}-\mathrm{CH}_{3}\right]^{+}$ions, i.e. in the case of primary alcohol and fatty acid derivatives (Figures $1 \mathrm{~A}$ and $1 \mathrm{~B}$ ). $\left[\mathrm{M}-\mathrm{CH}_{3}+\right.$ $\left.\mathrm{H}_{2} \mathrm{O}\right]^{+}$ions may thus constitute useful indicators of the presence of water in the system. 

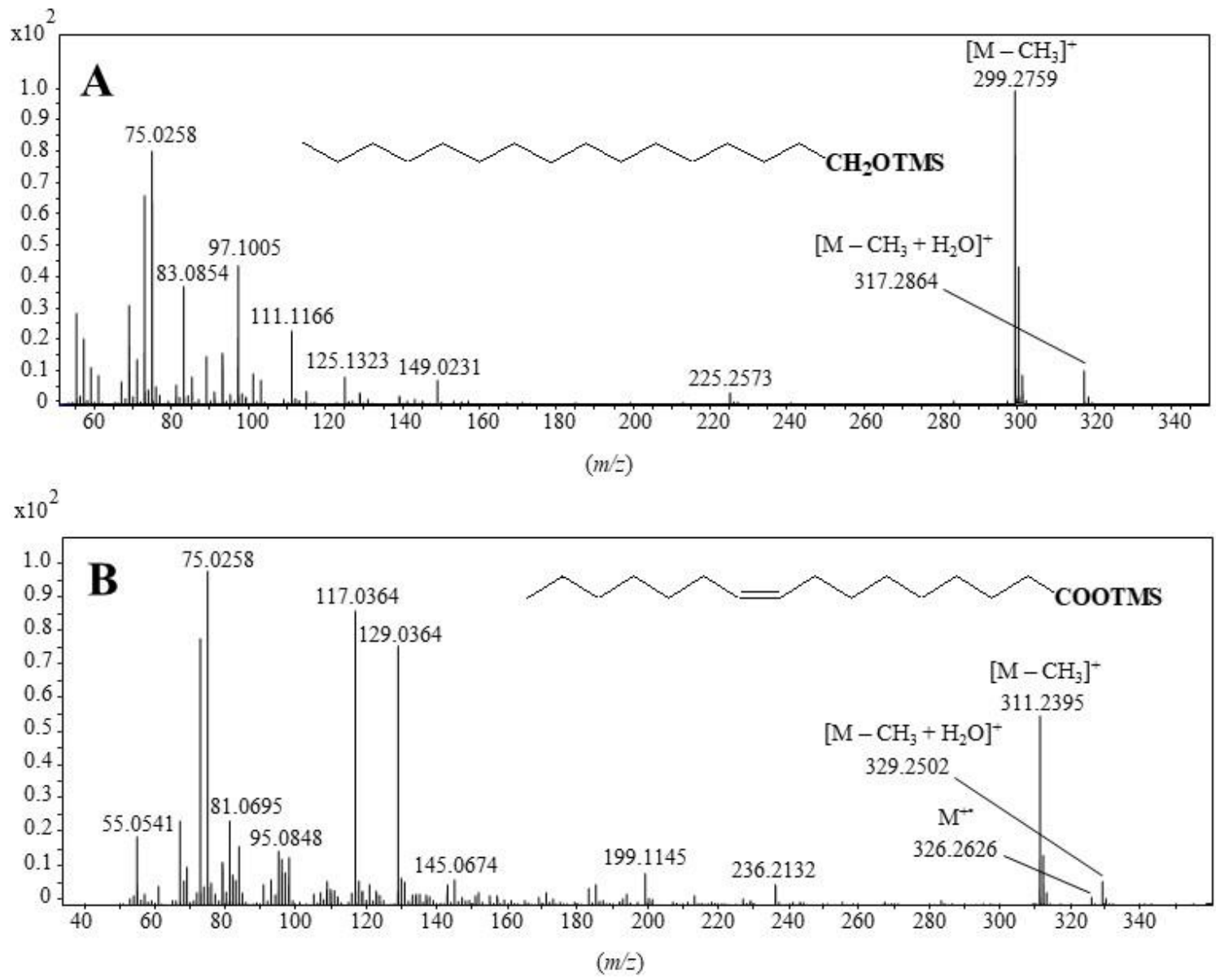

FIGURE 1 TOF mass spectra of TMS derivatives of hexadecan-1-ol (A) and hexadec-9enoic acid (B) showing the presence of $\left[\mathrm{M}-\mathrm{CH}_{3}+\mathrm{H}_{2} \mathrm{O}\right]^{+}$ions. 
$\mathrm{x} 10^{2}$

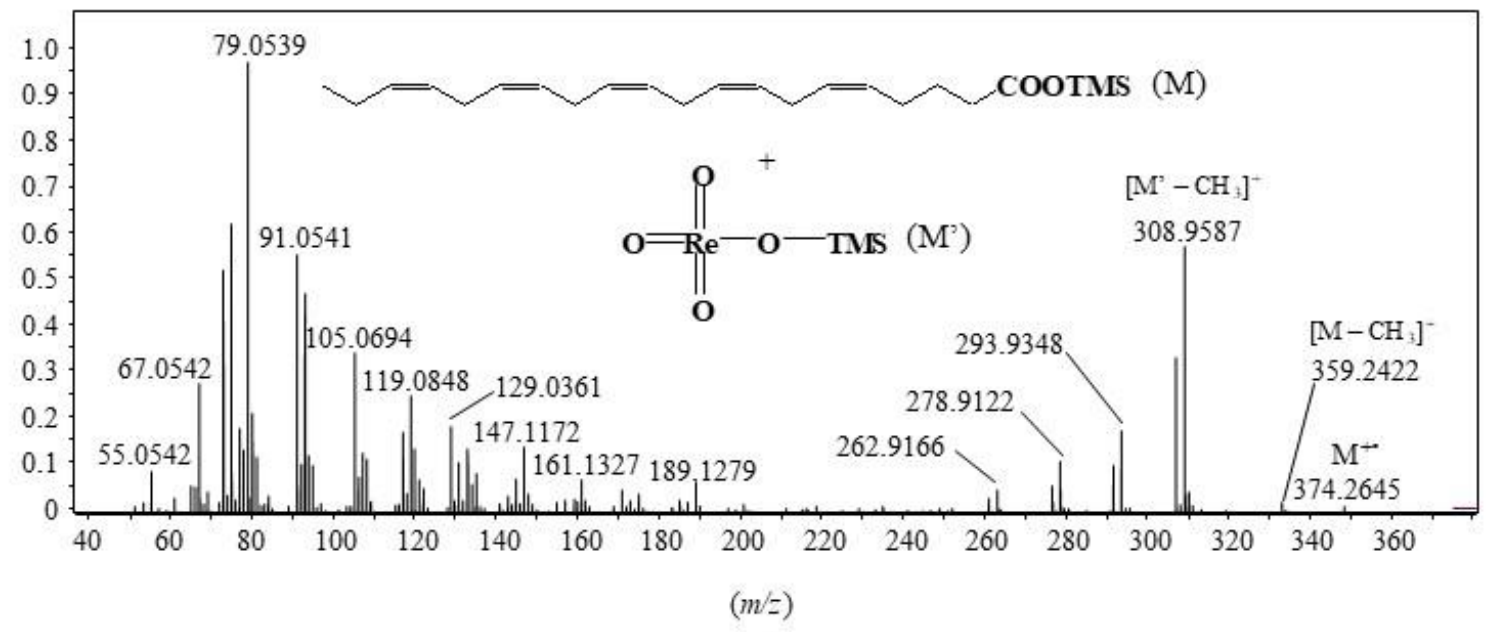

B

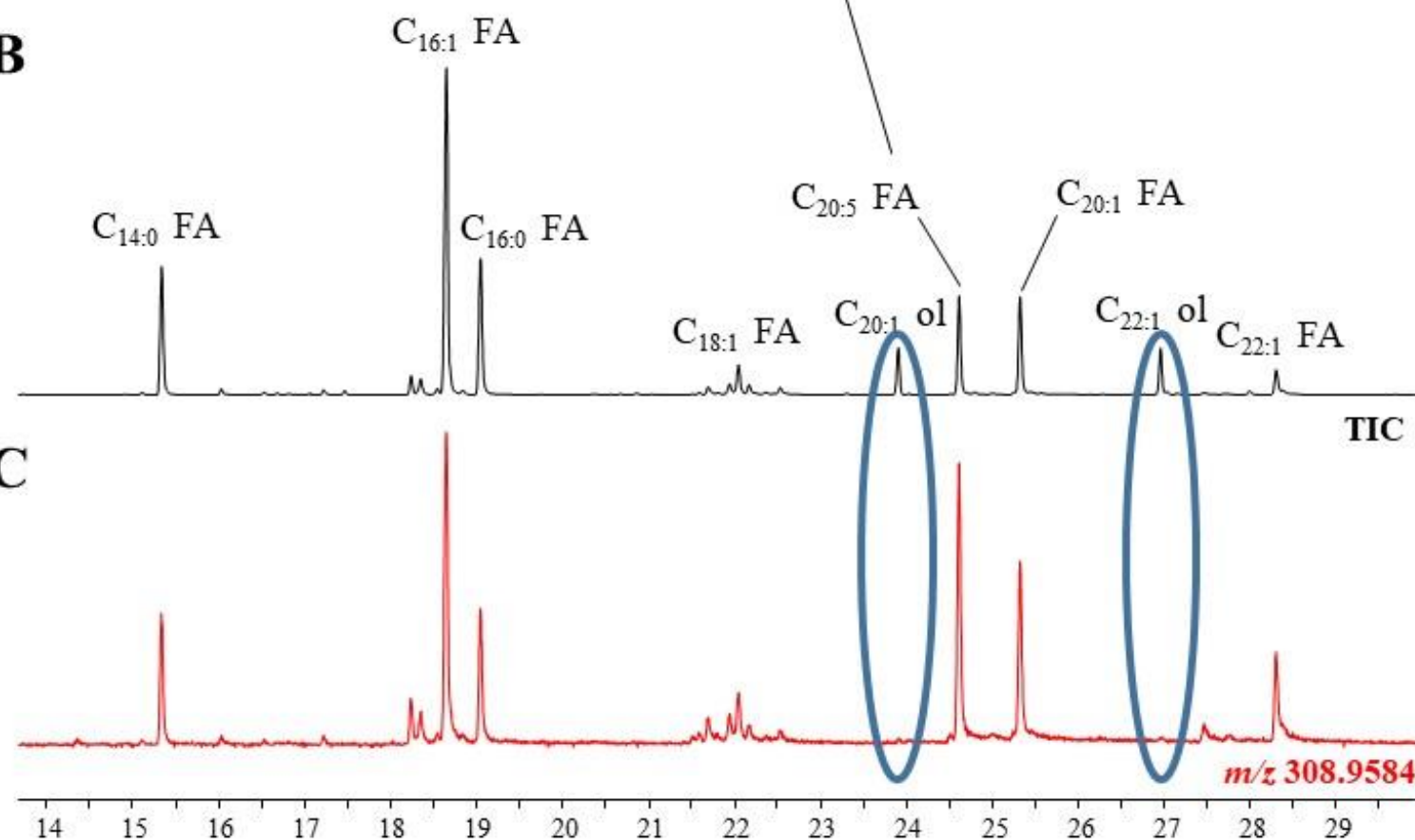

Retention time ( $\mathrm{min})$

FIGURE 2 TIC chromatogram (B) and mass chromatogram of $m / z 308.9584$ (C) of silylated total lipid extract obtained from sea ice $(0-3 \mathrm{~cm})$ collected in Baffin Sea (Canadian Arctic) during summer 2016. The TOF mass spectrum of the $\mathrm{C}_{20: 5}$ fatty acid TMS derivative obtained after subtraction of background and exhibiting intense trimethylsilyl perrhenate fragment ions is also shown (A). 
The presence of traces of oxygen in the carrier and collision gas or a leak at the junction of the capillary column and the mass spectrometer may induce the attack of filaments and result to the formation of the well-known Rhenium oxide $\mathrm{Re}_{2} \mathrm{O}_{7}{ }^{6}$ This oxide is converted to TMS perrhenate $\left(\mathrm{ReO}_{4} \mathrm{Si}\left(\mathrm{CH}_{3}\right)_{3}\right)\left(\mathrm{M}=323.9823\right.$ and 321.9794 for ${ }^{187} \mathrm{Re}$ and ${ }^{185} \mathrm{Re}$, respectively) by reaction with silylating reagents. ${ }^{7}$ Its fragmentation affords fragment ions at $\mathrm{m} / \mathrm{z}, 308.9584$ and $306.9551\left[\mathrm{M}-\mathrm{CH}_{3}\right]^{+}, 293.9343$ and $291.9321\left[\mathrm{M}-2 \mathrm{CH}_{3}\right]^{+}$and 278.9111 and $276.9088[\mathrm{M}-$ $\left.3 \mathrm{CH}_{3}\right]^{+}$. The presence of such fragment ions in the baseline of mass chromatograms is thus indicative of the presence of oxygen in the system and an alteration of filaments.

During GC-QTOF analyses of silylated natural lipid extracts, we could observe that the abundance of fragment ions of TMS perrhenate increased strongly under the peaks of silylated fatty acids (TMS esters) (Figure 2C). This increase was attributed to a reaction of $\operatorname{Re}_{2} \mathrm{O}_{7}$ in the source not only with the silylating reagent but also with TMS esters (Equation 2). The lack of reaction observed in the case of TMS ethers (Figure 2C) well supports the involvement of the proposed concerted mechanism (Equation 2).

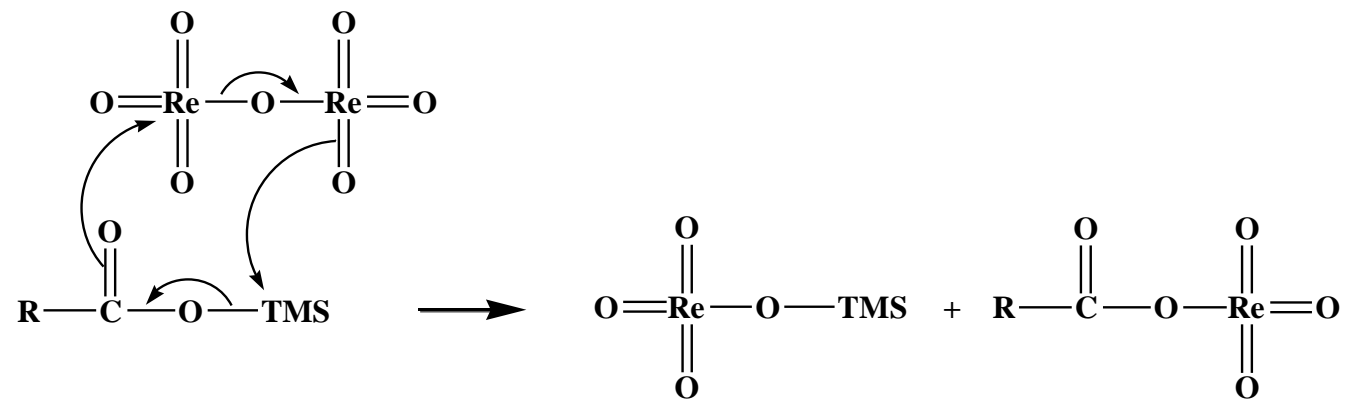

The detection of such fragment ions in TOF mass spectra of TMS esters, which is indicative of the presence of oxygen in the system, should be considered as alarming. Indeed, it indicates a deterioration of filaments, a possible accumulation of $\operatorname{Re}_{2} \mathrm{O}_{7}$ in the source (mainly at the level of the entrance lens) and a non-negligible desilylation of fatty acid TMS derivatives. It could also result to misinterpreting of mass spectra particularly in the case of polyunsaturated TMS esters exhibiting very weak molecular and $\left[\mathrm{M}-\mathrm{CH}_{3}\right]^{+}$peaks (Figure $2 \mathrm{~A}$ ).

In conclusion, we showed that the presence of traces of water in the collision gas may induce the appearance of unexpected peaks corresponding to $\left[\mathrm{M}-\mathrm{CH}_{3}+\mathrm{H}_{2} \mathrm{O}\right]^{+}$in mass spectra of TMS derivatives. The reaction with water can change the relative abundances of $\left[\mathrm{M}-\mathrm{CH}_{3}\right]^{+}$ fragment ions and lead to formation of product ions which cannot be formed directly from the original compound. The presence of traces of oxygen results to an alteration of filaments affording $\mathrm{Re}_{2} \mathrm{O}_{7}$, which can react with TMS esters in the ion source producing hindering TMS 
perrhenate. These observations should be useful for researchers who deal with GC-QTOF analysis of TMS derivatives.

\section{ACKNOWLEDGEMENTS}

Financial support from the Centre National de la Recherche Scientifique (CNRS) and the AixMarseille University is gratefully acknowledged. Thanks are due to the FEDER OCEANOMED ( $\left.\mathrm{N}^{\circ} 1166-39417\right)$ for the funding of the instrument employed.

\section{REFERENCES}

1. Pierce AE. Silylation of Organic Compounds; Pierce Chemical Co.: Rockford, IL; 1982.

2. Goad LJ, Akihisa T. Analysis of Sterols; Blackie Academic and Professional: London; 1997.

3. Sobolevsky TG, Chernetsova ES, Revelsky AI, Revelsky IA, Starostin AB, Miller B, Oriedo V. Electron ionization mass spectra and their reproducibility for trialkylsilylated derivatives of organic acids, sugars and alcohols. Eur J Mass Spectrom 2003; 9: 487-495.

4. Neta P, Farahani M, Simon-Manso Y, Liang Y, Yang X, Stein SE. Unexpected peaks in tandem mass spectra due to reaction of product ions with residual water in mass spectrometer collision cells. Rapid Commun Mass Spectrom 2014; 28: 2645-2660.

5. Tuytten R, Lemière F, Van Dongen W, Esmans EL, Witters E, Herrebout W, Van Der Veken B, Dudley E, Newton RP. Intriguing mass spectrometric behavior of guanosine under low energy collision-induced dissociation: $\mathrm{H}_{2} \mathrm{O}$ adduct formation and gas-phase reactions in the collision cell. J Am Soc Mass Spectrom 2005; 16: 1291-1304.

6. Kaoumi D. Investigations of the chemical compatibility of rhenium with uranium dioxide at elevated temperatures. PhD Thesis, University of Florida; 2001.

7. Schmidbaur H. Trimethylsilyl perrhenate - A nonionic reagent soluble in organic solvents for the preparation of perrhenates, In: Efficient methods for preparing silicon compounds, Academic Press, 2016; 21-25. 